\title{
THE IMPACT OF LIMITATION PERIODS ON ACTIONABILITY IN NEGLIGENCE
}

\author{
JOHN P. S. MCLAREN*
}

\begin{abstract}
The statutes dealing with limitations of actions with respect to negligence raise several problems-the commencement of the running of time, the problem of belated discovery, and the problem of whether the plaintiff is entitled to amend his action to include claims for others types of loss where the application for amendment is out of time. The author analyses how the courts have dealt with these problems and concludes that the statutes, as they presently exist, overly protect the defendant. He suggests that legislative change is necessary to give more consideration to the plaintiff in order to do optinum justice to all concerned.
\end{abstract}

\section{Introduction}

With the possible exceptions of the maze of adjective rules surrounding the law of defamation and the effect of the so-called doctrine of res ipsa loquitur' on the law of negligence, the impact of procedural law on the law of torts has largely eluded the critical gaze of the legal commentator. ${ }^{1}$ The present article has no pretensions of providing a comprehensive analysis of this somewhat diffuse area of inter-action. Indeed it takes as its frame of reference the fairly narrow question of contact and conflict between the law of negligence and the rules relating to limitation of actions. This is of course not the only area in which practical problems of reconciling the two branches of the law arise. However, the recent co-incidence of two decisions of Canadian appellate courts, ${ }^{2}$ legislative changes in the provinces of Alberta and Manitoba, ${ }^{3}$ and a report of the Alberta Uniformity Commissioners, ${ }^{4}$ all of which purport to inject some degree of rationality into the application of limitation rules to personal actions, perhaps justify a specific concern with this question at this time.

\section{Negligence actions and the time problem}

The first problem in applying limitation rules to negligence actions is to determine just when time starts to run. The statutory provisions which govern the whole subject of limitation periods are singularly uninstructive in this regard, for they seldom reveal anything more than vague phrases indicating that actions must be brought within a specified time after the cause of action arises." If the elements of a breach of duty and consequential damage or injury which are considered essential to actionability in negligence were always contemporaneous there would of course be no further need for amplification. The fact is, however, as the cases show, that these elements do not necessarily coincide. The time of the damage or injury may significantly post-date that of the causative act. Added to this is the further complication that

- LL.B. (St. Andrews). LL.M. (London), Assistant Professor. College of Law, the University of Saskatchewan.

1 A notable exccption in Canadian legal writing is W. F. Bowker, Limitation of Actions in Tort in Alberta (1962). 2 Alta. L. Rev. 41

2 Franks v. Cahoon (1967); 60 D.L.R. (2d) 237 (App. Div. Alta. S.C.). affirmed (1967). 63 D.L.R. (2d) 274 (S.C.C.); Long v. Western Propeller Co. Ltd. (1968), 67 D.L.R. (2d) 345 (Man. C.A.)

s An Act to amend the Law respecting Limitation of Actions in Tort, S.A. 1966, c. 49: An Act to amend the Limitation of Actions Act and to amend Certaln Provisions of Other Acts relating to Limitation of Actions, S.M. 1966-67, c. 32.

+ Proceedings of the 49th Annual Meeting of the Conference of Commissioners on Uniformity of Lesislation in Cansda 172-176. (1967).

- The term 'accrues' is used in some of the statutes. 
the damage or injury may be in existence in substantial advance of its discovery by the plaintiff. Stated simply, there are three dates which may be relevant to an assessment of when time starts to run-the date of the act, the date of the damage or injury. and the date of its discovery. The courts, therefore, are forced to give body to the statutory provisions by exercising a choice between these competing dates.

\section{The choice between breach of duty and consequential damage}

It is undoubtedly trite law that actionability in negligence depends on the existence of provable damage or injury. It is the latter element that consummates the action. Negligence "in the air' will not suffice." As the earliest occasion on which a cause of action may arise is that of the damage or injury, it should follow quite logically that the prescribed limitation period for the pursuit of a claim runs from that time. To choose any earlier period would be to leave the plaintiff in the thoroughly invidious position of not only not knowing that time was running but also of having no substantive claim to bring within the prescribed period. The 'tyranny' of procedural law would be assured. However, the fact that the defendant in the recent Manitoba case of Long v. Western Propeller Co. Ltd.' could argue, apparently with conviction, that the operative date is that of the act, suggests that practice has not entirely jibed with logic. The probable reason for this belated element of doubt is that Anglo-Canadian jurisprudence until recently left a perplexing element of ambiguity in its approach to this issue.

Until the 1950's English and Canadian case law revealed two lines of decision bearing upon the appropriate time for limitation periods to start running in negligence actions. In the first group, which comprised a series of situations in which excavations of the defendants caused damage at a later stage to the structures or land of the plaintiffs, the courts concluded that damage was essential to liability and it followed that time could only run from the date of the damage. Thus in Roberts v. Read" Lord Ellenborough, noting that the 'gravamen' of the action on the case was consequential damage, allowed the plaintiff's action for the withdrawal of support from his wall since he was within the required period calculated from the later collapse of the structure." Similarly, in the case of Backhouse v. Bonomi'" the House of Lords had no hesitation in maintaining that, in an action for damages for subsidence caused by the defendant's mining operation, the subsidence consummated the action and the time ran from that event."

The other group of cases involved situations in which the negligence of attorneys caused loss to their clients, the loss occuring or revealing itself substantially later than the errant act. Here the courts uniformly held that the operative time was the date of the negligent act rather

"The requirement of provable damage or injury was, of course, inherited from the older action of case. It constitutes one of the few remaining traditional distinctions between negligence and trespass. In the latter tort damage is not required and the trespassory act is suffteient to consummate the action.

: 1968), 67 D.L.R. (2d) 345 (Man. C.A.), affirming (1968), 65 D.L.R. (2d) 147 (Man. Q.B.).

$\times$ (1912). 16 East 215: 104 E.R. 1070.

S See also Gillon v. Boddington (1824). Ry. \& M. 161: 142 E.R. 654: Whitehouse v. Fellowes (1861), 10 C.B.N.S. 765; 171 E.R. 979

11 (1869), 9 H.L. Cas. 503; 11 E.R. 825.

11 Sce also Darley Main Colliery Co. Ltd. v. Mitchell (1886), 11 App. Cas. 127; West Leigh Colliery v. Tunnicliffe \& Hamisson Ltcl. |1908| A.C. 27; Crumbie v. Wallsend Local Bd., [1891], 1 Q.B. 503: Vanhorn v. Grand Trunk Rly. (1859), 18 U.C.Q.B. 356; Carron v. Gt. Western Rly. (1856), 14 U.C. Q.B. 192. 
than that of the consequential damage. The important element of actionability in these cases was deemed to be the breach of the duty and not the resulting loss. In Howell v. Young, ${ }^{\prime:}$ for instance, a solicitor was sued for negligence in representing that certain mortgages were sufficient security for a loan which his client made to a third party. The action which was brought later than the appropriate six years gauged from the date of the negligent advice was held to be barred. This was so even though the injurious implications of that advice, the loss of the interest and probable loss of the principal, did not develop or become apparent until after the expiry of that period. ${ }^{13}$

At first blush it might appear that there is a fundamental conflict between these lines of decision. Further reflection, however, would suggest that they are perfectly reconcilable. The obvious point of distinction is that in the latter group liability for negligence was seen in the context of a pre-existing contractual relationship. Thus, although a plaintiff might plead the action on the case rather than averring a breach of contract, the core of the action was deemed to be the same, the failure to live up to the level of care implied by the relationship. ${ }^{14}$ As Bayley, J., observed in the Howell case, even in the absence of an allegation of special damages, the plaintiff would have been entitled to nominal damages on the simple ground of the breach." In other words, the breach consummated the action. In the light of the contractual element, and the fact that by that time it was well accepted that in contract actions time ran from the date of the breach, the attitude of the courts is quite understandable. In the other group of cases, however, there was no contractual complication. The actions were purely tortious and involved situations in which consequential damage was necessary to convert the defendant's prior lawful act into an actionable wrong. ${ }^{16}$

The logical implication from the latter line of decisions should surely have been that in actions in tort, where there was no overlap with contract and where damage was of the essence (by definition this would have included negligence), the time of the sustaining of damage governed. Mirabile dictu for many years this rationalization escaped the minds of legal commentators. In the leading digests which discussed the matter ${ }^{1 \text { in }}$ the general consensus seems to have been that the rule as to the running of time in negligence was to be adduced from the 'negligent attorney' cases. There was in effect no distinction between contractual and purely tortious negligence when it came to applying limitation periods. The negligent act was the thing. The other cases were explained away as mere actions on the case in which tradition had it that damage was required for liability. Apparently they were to be confined to their special facts, and not to be considered as providing

1: (1826) 5 B. \& C. 259; 108 E.R. 97.

1: See also Short v. MeCarthy (1820), 3 B. \& Ald. 626; 106 E.R. 789: Smith v. Fox (1848). 6 Harc 386; 67 E.R. 1216: Hughes v. Twisden (1886), 56 L.J.Ch. 481; Bean v. Wade (1885) 2 T.I.R. 157: Wood v. Jones (1889) 61 L.T. 551.

1. For a discussion of the whole problem of the overlap of contract and torts law and the inconsistency of the courts in dealing with it, see Poulton. Tort or Contract (1966). 82 L.Q.R. 346 .

1. Supra, ת. 12, at 265.

ii The case of West Leigh Colliery $\mathbf{v}$. Tunnicliffe \& Hamrson Ltd.. supra, $n$. 11. is Instructive in this regard. The claim of the plaintiff for prospective damages expected as a result of the mining operations of the defendant was rejected on the specific ground that actionability depended on the cxistence of actual damage.

$16 a$ See, e.g., 24 Halsbury's Laws, 223-224 (3d ed. 1958); 12 Mew's Digest, 342-346 (2nd ed. 1926). 
any guidance in the context of negligence.": At least one judge was beguiled by this disingenuous line of reasoning. In Archer v. Catton \& Co. $L t d .^{1 \times}$ an employee brought an action against his employer for tortious negligence and breach of statutory duty in failing to prevent conditions which caused him to contract a chronic chest disease. Although he had been exposed to the noxious environment for some 17 years his action was not launched until 9 years after he had been moved to less dangerous work. However, it was brought slightly less than 6 years after the plaintiff had discovered his condition. Streatfield, J., relying on the combined authority of Dr. Charlesworth" "and Howell v. Young ${ }^{\text {nn }}$ and quoting from the former stated:

In an action for negligence, the cause of action accrues at the time of the negligence, because it is then that the damage is caused, even though its consequences may not become apparent until later."-1

Because the action was launched well after the prescribed six years taken from the termination of exposure to the deleterious conditions, the plaintiff was found to be out of time. The learned judge's reasoning did little offence to the facts of that case, for the defendant's negligence clearly continued up to and beyond the time when the plaintiff began to contract the disease. Isolated from the facts, however, it perpetuated the fallacy that injurious consequences inevitably co-incide with negligent acts and that the only problems which arise in practice relate to the belated appearance of existing damage.

Since the decision in the Archer case the courts in both England and Canada have successfully dispelled the confusion of former years by placing the relationship between tortious negligence and the running of limitation periods on a sound logical basis. In the Scottish case of Watson v. Winget Ltd.:- the House of Lords had to determine when time started to run in a reparation action brought by a machine operator against its manufacturers for the injury it had allegedly caused him. The choice lay between the date of the supply of the machine to the plaintiff's employers, which would have put him out of time, and that of the accident, which would have left him within time. The majority of the Court, applying what they considered to be a nccessary implication of the decision in Donoghue v. Stevenson,":: concluded that damage or injury was crucial to actionability in reparation and held that the operative date was that of the accident.": As the jurisprudence of England and Scotland is supposed to concur on the substantive features of negligence or culpa,,$=-;$ and since the Scottish statutory provision is

1: While the term 'negigence' is not specifically used in most of these cases. it is quile clear that the substantive issule wias the guc.stion of the improper conduct of the defendant in failing to take adequate care in rumning his operations or carrying on his activity.

is |1954| 1 All E.R. 896 (Assizes).

1: Charlesworth, The Law of Negligence 597 (2d fd. 1947).

2" Supra, n. 12.

2 Sturra, n. 18 , at 897.

$\because \because 1900 \mid$ S.C. 92 (H.L.).

$\because: 3932$ | A.C. 562 (H.L.).

$=$ Sumra, n. 22, per Lord Reid at 104-110, Lord Keith at 111-114, Lord Denning at 115-119. Viscount Simonds and Lord Morits of Bm+h-y-Gest dissonted on the Fround that the only valid interipretation of $s$. 6 of the Law Reform (Limitation of Actions. \& c.) Act. 1954, which referred to tinic running from the date of the act, neglect or default giving rise to the action . $\because$ Was that time ran from the wrongful act. Sec Viscount Simonds at 98-104 and Lord Morris at 119-122.

20 This wis the assumption made in Donoghue v. Stevenson, supra. $n$. 23, and recalled by Lord Denning in the instant case at 116. 
less abstract in its wording than its English counterpart, ${ }^{26 ;}$ this case may be considered of high authority in England. The same point of view was expressed in the subsequent English case of Cartledge v. E. Jopling Ltd.,": decided by the same court, in which the plaintiff brought an action for breach of statutory duty based on facts similar to those in the Archer case. In the course of his judgment Lord Pearce, speaking for the Court, stated:

Negligence and breach of statutory duty are not actionable per se and no cause of action arises unless and until the plaintiff can show some actual injury. Normally the injury is contemporaneous with the wrongful act, but it is not necessarily so." $*$

Although this statement may be considered as obiter dicta because the disease had caused material damage before the termination of the defendant's continuing negligence, taken with the earlier decision from Scotland it indicates in the strongest terms that English law is committed to the date of the damage or injury as the starting point for time to run." ${ }^{\circ}$

In Canada the stage was set for rationalization by the judgment of Laskin, J.A., in Schwebel v. Telekes.": The action was one brought by a client against a notary public, alleging his negligence in the settlement of a matrimonial dispute with the client's husband. The settlement involved the purchase of a house for the plaintiff, to which she was supposed to have sole legal and beneficial title. The property was conveyed to the plaintiff, but a little more than a year later the husband asserted a claim to an interest in the land. The resulting dispute was not resolved judicially until nearly 5 years later, when the claim of the husband was upheld. The writ was issued some 11 months thereafter. The question arose of whether time should be measured from the date of registration of the deed or from the date of the challenge by the husband, that being the earliest time at which damage could have been detected. The learned judge, speaking for the Ontario Court of Appeal, chose the former and held that the action was barred. He reached this conclusion on the express grounds that, although the plaintiff alleged negligence, her action was, according to accepted authority, necessarily based on breach of contractual duty:": As the breach constituted the legal wrong, time had to run from that date. At the same time he appeared willing to concede that the answer might be different where plain tortious negligence was the core of the complaint and proof of damage was required to complete the cause of action..$^{3:}$

The latter reflection was converted into an operative legal rule in the case of Long v. Western Propeller Co. Ltd..33 An action in negligence was brought by the owners of and passengers in an airplane, for property damage and personal injury suffered in the crash of the craft. The crash was alleged to have been caused by the negligent repairs carried out by the defendants. The machine had been repaired by them

213 Sec. 2(1) of the Limitation Act, 1939, as amended by the 1954 Act, refers to 'the date on which the uction accrued' as being the operative point in time. Cf. S. 6 of the 1954 Act. supra, $n .24$.

2: |1963! 1 All E.R. 341 .

2m Id., at 348.

:!) See Winfleld. The Lau of Tort 780-782 (8th ed. 1967); Salmond. The Law of Torts 773-774 (14th cd. 1965).

Bn [1967) 1 O.R. 541 (C.A.).

31 See also Frind v. Sheppard [1940] \& D.L.R. 455 (Ont. C.A.), rev. on other grounds [1941] S.C.R. 531.

32 Supra, n. 30. at 544

as Supra, n. 7. 
over 6 years earlier, while under different ownership. The mishap had occurred less than 2 years before the actions were launched. According to the statutory provisions then in force in Manitoba, the relevant periods of limitation were 2 years for personal injury and 6 years for damage to personal property." The obvious question was whether time was to be gauged from the date of repair or from that of the crash. The Court of Appeal, affirming the judgment rendered in chambers, held that the actions were in time. They reasoned that as this was an action in negligence, uncomplicated by the existence of a contractual nexus, the earliest date on which action could arise was the date of damage and accordingly that that must be the operative time for the limitation period to start running. Friedmann, J.A., exposed the ridiculous consequences of reaching any other conclusion when he remarked:

Under the statute [the plaintiff's] claim for personal injury had to be brought within two years after the cause of action arosc. If the crucial date is July or August, 1960, then their time ran out in July or August, 1962, but up to then neither had been injured and neither of them could sue any onc. I find it impossible to believe that their action could be barred before it cven came into existence.::

The message of the Court is clear and the underlying logic is irrefutable. It is to be fervently hoped that the decision in this case is the last word to be heard in Canada on this particular question."'

\section{The problem of belated discovery}

A problem which was not at issue in the Long case and which may arise independently of or concurrently with the previous problem is that of belated discovery of existing damage. Its incidence is not confined to any one type of damage or injury. Although it has been dramatized in the context of physical injury it may also be a decisive factor in cases of property damage and financial loss. Thus it is quite conceivable that the owner of a valuable vase will not notice the hair line crack caused by another's hand until some years later when he seeks to have it valued. Likewise, as already indicated, it is not unusual for one who has relied on the professional advice of another to discover at a substantially later date that the advice was ill-judged and that significant financial loss has resulted from his reliance.

In the context of physical injury two types of cases warrant particular concern. The first group comprises situations where the plaintiff, as a result of the alleged negligence of the defendant, contracts an insidious disease which it is impossible to detect, even by medical diagnosis, until it has reached an advanced stage of development. In the second group of cases the factual situation involves a surgeon or doctor who in conducting surgery or treatment has caused further harm to or left a foreign body inside the patient. The new malaise or the agent may lie dormant for many years before its effects become apparent to the patient.: ${ }^{-}$The risk of the latter's ignorance is heightened by the fact that his knowledge is likely to be the knowledge of the errant physician.

34 Limitation of Actions Act, R.S.M. 1954, c. 145, s. 3(1).

3.: Supra. n. 7. at 348.

:t: It is interesting to note in the recent case of Franks v. Cahoon. sumra. n. 2, which turned on the substantive character of negligence is a cause of nction. that. although the Courts rejected the contention that the causc of action was tragmented depending on the type of damage nccurring. they still stressed the need for some damasc as a pre-requisite of actionability.

3: See, e.g., Weinstein v. Blanchard (1932), 162 A. 601 (Ncw Jersey), in which 18 years passed between the operation and the discovery of a tube in the patient's body. 
If the surgeon or doctor is unaware of his mistake the patient will certainly be none the wiser. Where he is cognisant of it he may be tempted to conceal the true state of affairs from his charge." In all of these situations there is a significant danger that the plaintiff will be out of time, if the date of the negligent act, or that of the occurrence of damage or injury is held to govern.

In some instances the problem of discovery will be more apparent than real in that the facts will indicate some other saving factor, for example continuing negligence or a completely new cause of action. This is particularly true in the damage to land cases where the injurious consequences stem from a continuing operation on or dangerous condition of the defendant's land.:" It is also likely that the generally longer periods of time prescribed for the actionability of property damage minimize the chance that the plaintiff will be out of time. ${ }^{3 !}$

With one exception none of the Canadian limitation statutes provide any direction on the general problem of belated discovery. This is no doubt attributable to the fact that the device of limitation has been traditionally considered as a means for doing justice to defendants. That this is not suppositious is indicated by the 1962 Report of the U.K. Committee on Limitation of Actions in Personal Injury, when it said of limitation legislation:

In the first place it is intended to protect defendants from being vexed by stale claims relating to the long past incidents about which their records may be no longer in existence, and as to which their witnesses, even if they are still available, may well have no accurate recollection. Secondly ... [it $\mid$ is designed to encourage plaintiffs not to slcep on their rights, but to institute proceedings as soon as it is reasonably possible for them to do so ... Thirdly, [it] is intended to ensure that a person may with confidence feel that after a given time he may treat as being finally closed an incident which might have led to a claim against him. As Best C.J. put it in an old case, "[The Statute of Limitation] is, as I have often heard it called by grcat judges, an Act of peace".11"

In the parent English legislation the only concessions to the plaintiff, apart from what was considered to be a reasonable time for launching his action, were made in case of his disability (for example, infancy or insanity) or where the defendant was out of the jurisdiction. There, time started to run when the disability was removed, or when the defendant returned from foreign parts." These exceptions are uniformly adopted in the Canadian provinces. The only recognition that the problem of discovery may be a formidable one occurs in provisions which have been more recently enacted in some but not all of the Provinces, to the effect that where the cause of action is concealed by fraud, then time runs from the date when the fraud is first known or discovered."' The provisions on disability and fraudulent concealment, being of a general, pervasive character, would seem to apply in

3* See, e.f., Lakeman v. LaFrance 11959), 156 A. 2d 123 (New Hampshirc); Hinkle v. Hargens (1957) 81 N.W. 2d 888 (South Dakola); Schmucking v. Mayo (193i) 235 N.W. 633 (Minnesota). In cach of thesc cases it was found that the physician actively concealed the new injury he had caused to the plaintiff.

isn See, e.s., Battishill v. Read (1856). 18 C.B. 696. 714: Devery v. Grand Canal Co. (1875) 2 R. 9 C.I. 194 (Ex. Ch.): Fairbrother v. Bury R.S.A. (1889), 37 W.R. 544; Hole v. Chard Union $|1894| 1$ Ch. 293 (C.A.).

:19 Most of the existing Canadian statutes prescribe 6 years as the period for damage to personal or real property. Alberta has cut the period for both to 2 years, and Manitoba has reduced the perind for actions arising from damage to personal property to 2 years.

II Cmnd. 1829, 1962.

$\rightarrow 1$ The Statutes of Limitations, 21 Jac. 1, c. 16. s. 71 and 4 \& 5 Anne. c. 16. s. 19.

t: See the following Limitation Acts: R.S.A. 1955, c. 177, s. 6; R.S.M. 1954, c. 145, s. 4: R.S.P.E.I. 1951, c. 87, S. 3; R.S.S. 1965, c. 84, s. 4; R.O.N.W.T. 1956, c. 59, s. 4; R.O.Y.T. 1958 , c. 66 , s. 4. 
any appropriate case whether the essence of the plaintiff's claim is tortious negligence or breach of contract. + ts

In some Canadian jurisdictions special provisions exist governing the running of limitation periods against medical personnel and hospitals. ${ }^{4+}$ Where such provisions are in force they generally lay down that time runs from the date when the professional services terminate, in respect of the matter that is the subject of complaint. ${ }^{35}$ This type of provision may help the plaintiff in some situations, especially where there is a prolonged course of treatment." There is, however, no guarantee that it will assist in all cases of hardship. In the absence of any special legislation of this type it may be assumed that the general provisions relating to limitations apply and that the operative date is normally that of the occurence of the damage, whether or not that coincides with the date of the negligent act. Interestingly enough, the doctrinal difficulty in using the date of the damage that exists in the attorney cases appears to have no relevance where medical malpractice is concerned, for the courts have accepted that, contract or no contract, the essence of the plaintiff's claim is tortious negligence."

One province, Manitoba, has followed the British lead and grafted onto its existing Limitation Act a series of clauses, the effect of which is to toll the operation of the statute where it was impossible for the plaintiff, because of lack of knowledge, to have launched his action any earlier.* As with the United Kingdom Limitation Act of 1963, the operation of the remedial provisions are confined to actions for personal injury arising from negligence, nuisance or breach of duty, including breach of contract." In both jurisdictions the provisions which are largely identical in substance lay down a fairly involved procedure for the consideration of the matter. This is in contrast to the simplicity of the statutory provisions on concealed fraud, and reflects a very real concern on the part of the legislators lest they venture too far in the direction of the plaintiff's cause.: Under both statutes it is for the plaintiff to make out a prima facie case that 'the material facts relating to [the relevant] cause of action were, or included, facts of a decisive character which were at all times outside the knowledge, actual or constructive, of the plaintiff', either during the limitation period prescribed or not earlier than 12 months before the end of that period." ${ }^{\text {1 }}$ In either case

43 See Clark v. Woor, [1965] 2 All E.R. 353. A builder concealed the substandard quality of some of the bricks he used in facing a bungalow from the purchasers. He was held to be guilty of concealed fraud and the application of the limitation perlod was tolled accordingly.

14 See, e.g. The Medical Acts, R.S.B.C. 1960, c. 239 , s. 82; S.M. 1964, c. 29, s. 43; R.S.O 1960. c. 234: s. 43; The Medical Profession Act, R.S.S. 1965, c. 303, 5 . 55. In Nova Scotia and Alberta special provisions of this nature are contained in the reneral statute-R.S.N.S. 1967 , c. 168 , s. 2 (d) and S.A. 1966 , c. 49 , s. 56 .

4.5 In Alberta actions against hospitals 'may be commenced within one year after the cause of action arose'-The Limitation Actions Amendment Act. S.A. 1966, c. 49, 8. 57.

16 See, e.g. Gloning v. Miller (1953). 10 W.W.R. (N.S.) 414 (Alta. S.C.). A physician who had left forceps in a woman during a Caesaerian section discovered them over four years later and operated for their removal. The carrying out of this latter procedure was held to constitute the termination of services in the matter complained of. and, as the writ had been issued within a year thereafter, the plaintiff plained of, and, as the writ had been issued within a

17 For the doctrinal basis of the liability of medical men for malpractice, see Nathan. Medical Negligence 6-19 (1957).

4* The Limitation Act 1963, 11 \& 12 Eliz. 2, c. 47; The Limitation of Actions Amendment Act. S.M. 1866-67, c. 32. For useful comments on the English statute. see Dworkin (1964), 27 Mod. L. Rev. 199; Jolowicz [1964] Camb. L.J. 47.

49 Id.. S. 1(2): S. 4 [11A (2)] hereinafter such will be cited as though the statute was consolidated.

so This hesitance may well have been inspired by the cautious approach of the Davies Committee Report, supra, n. 40, at 15-18.

61 Supra, n. 48, s. 1 (3); 5. 11 A (1). 
the date of discovery must be within 12 months of the bringing of an action.:- While application may be made by the plaintiffs in both jurisdictions before or during the substantive proceedings, the Manitoba statute, unlike its British counterpart, does not require ex parte proceedings. The matter is left to the discretion of the court.:: Material facts are specifically defined as decisive "if they were facts which a reasonable person, knowing those facts and having obtained appropriate advice with respect to them, would have regarded at that time as determining, in relation to that cause of action, that ... an action would have a reasonable prospect of succeeding and of resulting in an award of damages sulficient to justify the bringing of the action".:1 The new rules cover not only the situation where the plaintiff does not become aware of his injury within the limitation period, but also cases where he knows that he suffered injury but does not know its nature or extent, or is unable to ascribe it to its true cause.:- Apart from these excepitions the statutory revisions preserve all existing defences." It is clear, therefore, that the leeway accorded by the new clauses does not extend to the situation where the plaintiff has already recovered damages but later discovers that his injuries are more extensive. The amending legislation does not purport to undermine the 'all or nothing' approach of the common law to damages. $:$ In both jurisdictions the amendments are tied in with existing survival legislation by specific cross reference.ir In Manitoba, which previously shared with the other provinces a bewildering complex of disparate and fragmented limitation provisions, the new provisions exist along side and are expressly related to a major rationalization of existing limitation legislation, which makes two years the common denominator for the running of time in most negligence actions. ${ }^{i 11}$

Outside the Manitoba legislation which itself is limited in scope, it is at best doubtful whether the Canadian courts can do much for plaintiffs by interpretation of existing general or specific statutory limitation provisions. It is possible that the general provisions on fraudulent concealment will be interpreted in a liberal vein to the benefit of some plaintiffs. The roots of this doctrine lie in Equity and the cases which have interpreted it, particularly in England, have sought to sustain its flexible equitable quality. in Thus, while the plaintiff may not be able to point to fraud in the strict sense of active deception, it may be enough that he can show wilful inaction, particularly where there is a relationship of trust between himself and the defendant."il Whether the doctrine would

s. Ibid.

is Cf. supra, n. 48, s. 2(1); s. $11 \mathrm{~B}(1)$.

at Supra, n. 48, s. $7(4)$; s. $11 G(6)$. Accolding to these scctions 'appropriate advice' means the advice of competent persons qualificd, in their respective spheres, to advise on the medical, legal and other aspects of the facts or circumstances relating to the plaintiff's action.

s. Supta, n. 48, s. $7(5) ;$ s. $11 \mathrm{G}(5)$

st Sujra, n. 48, s. $1(4) ;$ s. 11 A (3)

$\therefore$ It does not affect the authority of Fitter v. Veal (1701). 12 Mod. Rep. 542; 88 E.R. 1506 in which the plinintiff who had already recovered minimal damases for assault and battery from the defendant was not pernitted to launch a second action when he discovered that the injuries were far more serious than he had at first supposed. is supra, n. 48, s. 3; s. 11C.

n9 The Limitation of Actions Amendment Act, S.M. 1966-67, c. 32, s. 5 Schedule A; \$ 6-21.

(3) See, e.g. Bulli Coal Mining Co. v. Osborne, 11899| A.C. 351 362-363, (P.C.); Oelkers v. Ellis, [1914] 2 K.B. 139: Lunn v. Bnntber, $[1930 \mid 2$ K.B. 72.80.

1:1 See Beaman v.A.R.T. Ltd. 11049) I K.B. 550 (C.A.) (ballce-bailor): Kitchen v. R.A.F. Association, [1958] 2 All E.R. 241 (C.A.) (solicitor-clicnl): Joncas v. Pennock (1962), 32 D.L.R. (2d) 756 (App. Div. Alta. S.C.) (solicitor-client): Clark v. Woor, supra, n. 43 (builder-purchaser). 
be extended as far as it has been by some American courts, which have, in the context of medical malpractice, found 'constructive fraud' in the mere silence of the defendant with probable knowledge of the negligence, is debatable."i2 Even with a liberal interpretation of the doctrine, however, the expedient would be at best a partial one.

In cases of malpractice governed by separate legislation it is naive to expect anything but rigid interpretation from Canadian courts. It seems that the judges have firmly closed the door to mitigation of the unfortunate side-effects of the existing provisions by importing exclusionary clauses from the general statutes or remedial concepts from Equity. In Miller v. Ryerson it an action of malpractice was brought by a child of 9 against a doctor who had treated him nearly 4 years before. The plaintiff alleged that as a result of the treatment he had become deaf and dumb. It seemed that the supposed effects of the treatment did not become apparent until three years after the treatment and within a year of the starting of the action. According to special legislation applying to the medical profession, actions had to be started within one year from the date when the professional services complained of terminated. The Ontario Court of Appeal, applying the statute, held that the action was barred. The judges specifically rejected the plaintiff's argument that, since he was an infant, the disability rule in the general limitation statute should apply. As Meredith, J., put it:

Nor can the provisions of any Statute of Limitation, respecting persons under disability, be incorporated into this Act. It is not an act respecting limitation of actions, but one passed mainly for the benefit of the medical profession; nor is the provision in question an amendment of the provisions of any such statute, but simply a provision for the special protection of the registered members of that profession. ${ }^{\text {ii" }}$

Boyd, C.J., recognized the unfortunate position of the plaintiff when he remarked:

The result may be that, if no disastrous consequences are manifest till a year after the close of the professional employment, the right of action is gone or never arose as an available remedy.

However, he consoled himself with the thought that this was a matter for the exclusive attention of the legislature. A similar conclusion was reached by the Saskatchewan Court of Appeal in the case of Tremeer v. Black. ${ }^{\text {: T }}$ There the plaintiff alleged that in the course of a gall bladder operation performed in 1916 the defendant had negligently left a tube inside him. The presence of the tube was not revealed until a further operation in 1923 which was conducted by another physician. The operative limitation period under the Medical Professions Act was 6 months from the date when, in the matter complained of, the professional services terminated. The plaintiff sought to argue that the application of the provision was subject to the equitable doctrine of fraudulent concealment which would have made the date of the second operation the crucial time. Following the reasoning of the earlier Ontario case, the Court con-

ii: See Burton v. Tribble (1934), 70 S.W. 2d. 503 (Arkansas): Morrison v. Acton (1948), 198 P. 2d. 590 (Arizona): Perrin v. Rodriguez (1934), 153 So. 555 (Loulstana).

(i) In jurisdictions which at one time did not or stlll do not have an exception in their statutes relating to concesled fraud the courts have achicved or may achieve the same results by applying the equitable doctrine itself. See Gibbs v. Guild (1882). 90 Q.B.D. 59 (C.A.)

04 (1893), 22 O.R. 369 (C.A.).

45. Id., at 373 .

co Id., at 372 .

o7 [1924] 2 W.W.R. 97. 
cluded, not without regret, that the special limitation period relating to medical men was absolute and admitted of no exceptions which might be applicable to general limitation legislation. Accordingly, they held that the action was barred.: If these cases represent the limits of judicial ingenuity where appeal is made to accepted remedial concepts, it bodes ill for the plaintiff who can only plead innocent ignorance.

In the case of the general statute where fraud or disability are not in question the courts are forced back to an interpretation of the phrase 'within $\mathbf{x}$ years after the cause of action arose [or accrued]'. Here, depending upon what the court finds to be the essence of the relationship between the plaintiff and defendant, prima facie the operative time will be the date of the act or the date of the injurious consequences. The Canadian Courts, like their English counterparts, seem to have closed the door to a remedial gloss to accommodate the problem of belated innocent discovery where breach of contract constitutes the heart of the plaintiff's action, and it is safe to conclude that the time of the negligent act is crucial.: In contrast, where purely tortious negligence is at issue, the dearth of any judicial guidance in Canada ostensibly leaves the question open. In approaching the problem the Canadian courts might be said to have two courses open to them. They can follow the pre-1963 English case of Cartledge v. E. Jopling Ltd. " in which the House of Lords, not without qualms, and happy in the knowledge that remedial legislation was on its way, refused to read the Limitation Act in such a way as to allow time to run from the date of discovery rather than from the earlier date of material injury. (The plaintiff had contracted pneumoconiosis in the course of his work as a steel dresser. Although the disease had begun to develop by 1950, the date when working conditions improved, he only discovered this some years later. His action for breach of statutory duty was launched late in 1956, within the prescribed six years taken from discovery but outside that period measured from the emergence of the disease.) Alternatively they can opt for the approach taken by a number of U.S. courts in cases involving insidious diseases and medical malpractice, where the latter have constructed remedial glosses in favour of the plaintiff who belatedly but innocently discovers his adverse condition." The classic American decision in this context is that of the Supreme Court in Urie v. Thompson. $\because 2$ On facts similar to those in the Cartledge case the Court interpreted the abstract limitation provision in the Federal Employers' Liability Act so as to allow the plaintiff's action in negligence for damages even though it was clear that he had contracted the disease earlier and was, on a strict interpretation of the statute, out of time.:" Justice Rutledge, speaking for the Court, rationalized the decision in these words:

is Jbid., per Haultain, C.J., at 99-100; MacKay, J.A., at 102-103; Martin. J.A., at 104-105. is Schwebel v. Telekes, supra, n. 30; Frind v. Shemard, supra, n. 31.

:I Supra, n. 27. (1958). 322 P. 2d. 460 (Callfornia): Brush Beryllium Co. v. Meckley (1960), 277 F. 2d 809: Ricciuti v. Voltarc Tubes Inc. (1960), 277 F. 2d 809; Quinton v. United States (1962), 304 F. 2d 234: Fernandi v. Strully (1961), 173 A. 2d 277: Mitchell v. American Tobacco Co. (1960). F. Supp. 2d 406; Spath v. Morrow (1962), 115 N.W. 2d 581 (Nebraska): Seitz v. Jones (1961). 370 P. 2d 300 (Oklahoma1. For an instructive account of developments in malpractice litigation in the U.S. sce Lillich. The Malpractice Statute of Limitations in New York and Other Jurisdictions (1962), 47 Corn. L.Q. 339.

i: (1949). 11 A.L.R. $2 d 252$.

i3 The Act in question. which allowed negligence claims by employecs against their employers for injury incurred in the course of their employment. merely made reference to the limitation period running from the time the cause of action accrued. 
.. [I]f we assume that Congress intended to include occupational diseases in the category of injuries compensable under the Federal Employers Liability and Boiler Inspection Act mechanical analysis of the accrual of petitioner's injuries-whether breath by breath or at one unrecorded moment in the progress of the disense can only serve to thwart the Congressional purpose. We do not think the humane legislative plan intended such consequences to attach to blameless ignorance. Nor do we think those consequences can be reconciled with the traditional purposes of statutes of limitations, which conventionally require the assertion of claims within a specified period of time after notice of the invasion of legal rights. . . . There is no suggestion that Urie should have known that he had silicosis at any earlier date. "It follows that no specific date of contact with the substance can be charged with being the date of injury, inasmuch as the injurious consequences of the exposure are the product of a period of time rather than a point of time; consequently the afflicted employec can be held to be 'injured' only when the accumulated effects of the deleterious substance manifest themselves. . . ."it

It is interesting to note that the undoubted justice of this approach attracted two of their Lordships in the Cartledge case. ": They felt bound to distinguish it however on the ground that it involved the interpretation of a limitation clause in the particular statute which gave the substantive right to sue. The same reasoning, they felt, could not be applied with abandon to general limitation legislation. 'i; This is the type of argument which would strike a responsive chord amongst Canadian judges. Any court applying a gloss to a general limitations act would have the difficult, if not impossible, task of defining the scope of the exception. Is the exception to be applied indiscriminately to all causes of action? If not, then to which actions should it extend? Should it apply where it is accepted that a cause of action arises without the necessity of any material damage? Should it only apply to personal injury cases; or extend to property damage? These are the type of embarrassing policy questions which would arise and would be enough to give most judges reason to choose caution over valour. It is instructive in this regard that Laskin, J.A., one of the more adventurous spirits within the Canadian judiciary, did not feel at all justified in re-interpreting the Ontario Limitations Act to assist the disadvantaged plaintiff in Schwebel v. Telekes."- Even if it be conceded that his decision was dictated by the sheer weight of existing authority, there is still little reason to be sanguine over the Canadian courts' ability to wander too far from accepted canons of construction where there is no specific precedent to hamper them. In the U.S. decisions that have gone as far as to interpret general limitation provisions to assist the plaintiff, it is noticeable that the result has been achieved by a direct appeal to the justice of the situation, coupled with an unquestioning acceptance of the Urie decision.: This type of frank creativity holds little attraction for the judiciary in this country. Accordingly, in the absence of specific legislative amendment in Canada, it is unlikely that the equities running in favour of the defendant will be balanced by any greater concern for the difficulties of the plaintiff.

\section{Limitation Periods and Diversity of Damage in Negligence}

An associated problem which sometimes faces the plaintiff is whether he is entitled to amend his action in negligence to include claims for other types of loss where the application for amendment is out of time.

it Sumra. n. 72. at 261-262.

is Scc, supra, n. 27.

it Supra. n. 27. per Lord Evershed at 345 and Lord Pearce at 350-351.

-: Supra, n. 30

is Sec Riccuiti v. Voltarc Tubes Inc. (1960), 277 F. 2d 809; Brush Beryllium Co. v. Meckley (1960), 284 F. 2d 797. 
The problem was highlighted in the recent Alberta case of Franks v. Cahoon." The plaintiff suffered both property damage and personal injury in a road collision. The plaintiff started an action in negligence for the recovery of damages for harm to his property within the all embracing 12 month limitation period then prescribed by the Vehicles and Highway Traffic Act." Later, after the expiry of the 12 month period, he sought to amend his claim to include damages for personal injury. Both the Appellate Division of the Supreme Court of Alberta and the Supreme Court of Canada upheld the order allowing an amendment." The courts saw the controversy as a doctrinal one between an interpretation of negligence which deemed that there was one cause of action, which would mean that the plaintiff had started his action in time and was entitled to amend and a second interpretation which deemed there to be as many causes of action as there were types of damage, which would clearly put the plaintiff out of time in seeking to pursue a new cause." Strange though it may seem, the former contention was revolutionary in that it was not supported by direct authority. The latter was bolstered by a line of Anglo-Canadian decisions following the 19th Century English authority of Brunsden v. Humphrey.:3 In that case a majority of the Court of Appeal had allowed a taxi driver, who had already successfully sued for damages to his cab, to launch a second action for personal injury. They held that the causes of action were separate and distinct and it followed that the doctrine of res judicata could not apply.

The rationale in the Franks case is contained in the judgment of Porter, J.A., in the Alberta appellate court." As a prelude to adopting an independent approach, he noted that in Brunsden v. Humphrey the two judges at the Queen's Bench level had reached the opposite conclusion to that of the Court of Appeal; ${ }^{\times s}$ that Lord Coleridge, C.J., had dissented from the views of his brethren and that one of the latter," Bowen, L.J., had expressed doubts about his solution to the problem. ${ }^{{ }^{7}}$ The decisive reason for doubting the validity of the case, however, was that its ratio was coloured by a lingering nostalgia for the forms of action, at that time only recently abolished by the Judicature Acts. He cautioned against a return to the 'trammels' of the ancient forms and quoted with strong approval a comment to that effect in the judgment of Denning, M.R., in Letang v. Cooper. ${ }^{* *}$ An appropriate modern interpretation of the tort of negligence, he contended, was "a breach by the defendant of the duty which he owed to the plaintiff at common law which resulted

is Supra, n. 2.

Ro Vehicics and Highway Traffic Act, R.S.A. 1955, c. 356, s. 131 (1). later repealed 1966, c. 49 , s. $4(2)$.

1 Supra, n. 2.

*: It appears to be well established that an amendment cannot be made which introduces a new cause of action after the limitation period has expired. The locus classicus is Weldon $v$. Neal (1887), 19 Q.B.D. 394. The broad rationale of the case. which is that amendments should not be allowed if they prejudice the rights of opposins parties, has been affirnicd in a number of Canadian cases. For cases approving of the principle in the present limited context. see Jones v. Hambleton (1922), 23 O.W.N. 466 (Ont. H.C.); Ellis v. Pelton, |1933| O.W.N. 191 (Ont. C.A.); Schubert v. Sterling Trust Corp.. |1935| O.W.N. 133 (Ont. H.C.): Roval Bank of Canada v. Acadia School Div. No. 8, $|1943| 2$ W.W.R. 126 (Alta. S.C.).

*3 (1883), 14 Q.B.D. 14i, (C.A.). For affirmative Canndian decisions, sec Sandberg $v$. Giesbrecht (1963). 42 D.L.R. (2d) 107 (B.C.S.C.) and Cleveland v. Yukish (1965), 51 D.L.R. (2d) 208 (Ont. Co. Ct.). Contra: MeDonald, J.A.. in Winter v. Dewar (1929) 2 W.W.R. 518, 523-524 (B.C.C.A.).

84 (1967), 60 D.L.R. (2d) 237, 238-240.

85 (1883), 11 Q.B.D. 712, per Pollard, B. at 713-714 and per Lopes, J. at 714-715.

Ho Supra, n. 83, at 152-153.

ni Id., at 150 .

8 [1965] 1 Q.B. 232, 239 (C.A.). 
in damage to the plaintiff. The injury to the person and the injury to the goods, and perhaps the injury to the plaintiff's real property and the injury to such modern rights as the right to privacy flowing from negligence serve only as yardsticks useful in measuring the damages which the breach caused." He concluded accordingly that "the factual situation' which gave the plaintiff a cause of action was the negligence of the defendant which caused the plaintiff to suffer damage. This single cause of action cannot be split to be made the subject of several causes of action."

It is encouraging to see a Canadian court consciously attempting to inject an element of rationality into the present pattern of tortious liability, and moreover departing from hallowed English authority in the process. However, although the decision purports to introduce some added symmetry into the description of negligence as a tort, this is clearly subordinate to the procedural significance of the case. As courts have often maintained, it is thoroughly desirable, for the orderly and expeditious administration of justice, that all claims stemming from a single tortious act be dealt with together." This is particularly appropriate where the situation involves one plaintiff and one defendant. Nevertheless, this ideal should not deflect attention from the fact that in some instances the plaintiff is faced with serious logistic difficulties in framing his action. This would seem to be especially the case with personal injury, where he is faced with the dilemma of, on the one hand, being compelled by the 'all or nothing' approach of the common law to damages and a sometimes hopelessly inadequate limitation period, to sue with all haste, and on the other, to delay his action because of the uncertainty as to the viability of his claim or as to the nature or extent of his injury. The tendency towards vacillation may also be compounded by the fact that some eminence grise, usually an insurance company, is holding up or pulling the strings of litigation to further its own interests rather than those of the plaintiff:": Given this exposure to conflicting demands, it is little wonder that plaintiffs on occasion find themselves to be the victims of time. The Franks decision represents a sincere recognition of this problem and provides a solution. The solution is, however, only a partial one and may itself spawn new practical problems.

In the first place, the decision only has reference to negligence and does not purport to tackle the problem of amending outside time as it affects other tort actions. It affords no assistance to the plaintiff who launches separate claims in a tort like trespass where the cause of action appears to be fragmented, or to the plaintiff who seeks to change his cause of action completely. These problems were of course not within the ambit of the issue posed in the case and it is totally unrealistic to argue that the two Courts might have dealt with them incidentally. This would have meant not only questioning the premises of accepted author-

\footnotetext{
-" Supra, n. 84, at 239.

:11' Id., at 240 .

:1 See, e.g. Kellar v. Jackson, $|1962|$ O.W.N. 34 (Ont. H.C.).

!: See, e.g., Arrow Transit Ltd. v. Tank Truck Transport (1968), 65 D.L.R. (2d) 683 (Ont. H.C.) in which Wilson, J.. rejected a motion to dismiss a plaintiff's second action for damages for personal injury which introduced an additional defendant even though he was already suing for damagc to his property. One of the reasons for the rejection was the fact that the Initial action was brought at the bchest of the plaintiff's insurers. As the judge put it. "Iw/hile the court is opposed to multiplicity of actions, there are real problems arising out of conflicts between an insured and insurer when they do not co-operate to bring one action that would suffice for all purposes."
} 
ity which rejects amendment where a new cause of action is raised, but also a major analysis of the existing pattern of tortious liability. The continued existence of these problems, however, does illustrate the limitations of judicial ingenuity as a substitute for what is really required, a broad statutory discretion to allow amendment where justice demands it.:: Secondly, in rejecting the Brunsden case as an obstacle to the plaintiff's application to amend outside the prescribed limitation period, the two courts seem to have ruled out any possibility of plaintiffs getting round the res judicata rule. Thus, if a plaintiff is unfortunate enough to get an expeditious judgment for one claim in negligence, it now seems impossible for him to launch a subsequent negligence action even though it relates to a different type of loss.:":i: The plaintiff's fate, therefore, may depend entirely on the size and complexity of his initial claim and the speed with which it can be processed by the court system. In defence of the decision in the case it may be said that, with the state of existing authority on the right to amend and the absence of any statutory discretion, the Courts in their desire to do justice to the particular plaintiff chose the only available path. As an added element of justification it should be pointed out that the plaintiff is less likely to be caught by an expeditious judgment than he is by the expiry of the prescribed limitation period. Thus it can be argued that the beneficial effects of the decision are likely to be greater and the ills less significant than if the opposite course had been followed. Finally, the decision may, if applied with abandon, be productive of conflict with the spirit of limitation legislation in several Canadian jurisdictions. In two provinces, Saskatchewan and Prince Edward Island, and both the Arctic territories, all of which retain the limitation pattern laid down by the Uniform Act of 1931, "' the limitation period for personal injury is two years while that for property damage is six years.": Further, in the recently amended Manitoba Legislation, two years is prescribed for personal injury and damage to personal property, and six years for damage to real property."'Ti The question arises whether a plaintiff, in addition to relying on the Franks case to amend out of time, can also use the single cause of action notion to gain recognition of a subsequent or an isolated action where the previous claim or the action itself is outside the shorter but within the longer period of time." In effect can the plaintiff claim the benefit of the six year period whatever the type or less he has suffered? If he can, then it seems to the writer that the courts will be openly subverting the policy of the statutes in specifying different periods. If he cannot, which is more likely, then the doctrinal basis of the decisions in the Franks case loses its claim to universal validity.

13. See infra, p. 267.

n3a See Dearden v. Hey (1939), 24 N.E. 2d 644 (Missachusetts) for the relationship betueen the one cause of action concept and res judicata.

w1 For the text of the Untform Act. sce the Proctedings of the 14th Annual Mecting of the Commissinicers of Uniformity of Lesislation in Canada, 38 (1931).

ns The Statute of Limitations, R.S.P.E.I. 1951, c. 87, 5. 2 (1) (d) \& (g): the Limitations Act. R.S.S. 1965, c. 84. s. 3(1)(c)\&(d): R.O.N.W.T. 1956. c. 59. s. 3(1)(d)\&(c): R.O.Y.T. 1958. C. 66. S. 3111 (d)\&lel.

(11) The Limitalion of Actions Ainendment Act. S.M. 1966-67. c. 32. s. $3(1)$ (f) \& (e).

:1: The only judge in the Frank case that setms to have recognized the possibility of conflict between the decision and limitation legislation was Johnson, J.A.. Who dissented in the Appellate Division of the Alberta Supreme Court. Even then the reference was oblique, appearing in a quote from Bowen. L.J., in the Brunsden case. See, suma, n. 84, at 245 . 


\section{Negligence, Limitations and Legislative Reform}

From the preceding comments it can be seen that there are both real and imagined limits to the inventiveness of the courts in dealing with limitation periods in the context of negligence actions. The practical consequence is that little has been done to tackle the problems which those periods present for plaintiffs. Limitation statutes still exist primarily to protect defendants. What needs to be recognized by lawyers is that limitation provisions should represent a compromise between the interest of the plaintiff in having the merits of his claim heard when his case may be viewed in the most favourable light and the interest of the defendant in being free from the interminable threat of legal proceedings. Both claims are worthy of consideration and need to be counterbalanced in such a way as to do optimum justice to both. Now, while the courts may in certain instances have been more timorous than necessary in their approach to the problem, they have to a large degree been the victims of a complex and ambiguous legislative system which it is beyond the capacity of any court to rationalize successfully. The suggestion is ventured that a final solution to the inequities that exist awaits an extensive rationalization and up-dating of limitation legislation. While the present concern is with negligence, it is clear that the solution to that problem is tied in with a broader re-assessment of policy in relation to personal actions in general, and this is reflected in the comments that follow."ss

The most depressing feature of the present legislative framework is the proliferation of special limitation periods which are dispersed throughout the statute books. In addition to those laid down in the general acts, special truncated periods are prescribed in legislation relating to automobile accidents, fatal accidents, and to the liability of municipalities, medical men, hospitals, public servants and public authorities.": In some instances the plaintiff not only has the burden of beating a short limitation period, but is also required to give notice as a condition of actionability. '"'!' This fragmentation has little to commend it in either form or substance. It means that it is impossible to find the law on limitations in one place and it has led to a certain amount of casuistry as courts try to determine whether the general act or the special legislation applies in the facts before them. '"1' The greatest evil, however, is that it places some individuals and groups in an unjustifiably privileged position when it comes to protection from litigation. Not only are they benefited by minimal limitation periods, but they are insulated from the equitable exceptions contained in the general statutes. "'" It may be seriously questioned why public and local authorities are more worthy of concern in this respect than the individual. If the argument is that limited funds are in jeopardy, then logically the same protection should be afforded to the individual who is of slender means. If the rationale is that public funds should not be dispensed with abandon for compensatory

"1) In this respect it is encouraging that Manitoba and Alberta have recently made significant changes in thelr respective statutes and that there appears to be a renewed Intercst in limitations amongst the Uniformity Commissioners. See supra, nn. 3 and 4.

n! See Bowker: suprn, n. 1, for an Indication of the confused situation in Alberta. The position in the other common law provinces is similar.

1+11 Id., at 45-46.

inl Id., at 43-53.

1v: Sec, e.G., Miller v. Ryerson, supra, n. 64 and Tremeer v. Black, supra, n. 67. 
purposes, this may be countered by the contention that if the community wishes to reap the benefit of public enterprise then it should be prepared to shoulder the cost, including that of damage which the undertaking causes to others. In fact it may be argued that liability is more supportable in these cases in that the expense may be distributed throughout the community. Why medical men should be in a more favoured position as regards protection from suit than their counterparts in other professions is again hard to fathom. The effects of medical malpractice are likely to be just as serious, if not more so, than those of negligence in other professional contexts. If it be contended that the physician is in a particularly exposed position because of the difficult decisions of professional judgment that he has to make, this is surely a problem which should be dealt with on the merits rather than by procedural immunity from suit. ${ }^{103}$ The likely consequence of present limitation legislation as it applies to medical men is to confirm people in the view that physicians are more concerned with professional solidarity than with the welfare of their patients.

If it be accepted that this diversity of approach is undesirable then two remedial measures are required. In the first place, the limitation periods need to be brought into line with those laid down in the general limitation statutes. Secondly, it is desirable that all operative provisions are contained within the general statute rather than scattered in haphazard fashion throughout the rest of the statute book. Thus, even where special provisions are retained as desirable, for example the termination of services as the operative date for time to start running in the case of doctors and hospitals, they will nevertheless be subject to equitable provisions contained in the general legislation. As the Alberta Uniformity Commissioners recently pointed out, it would be possible in this way to construct a comprehensive code relating to limitations. ${ }^{104}$

Not only are these changes desirable in principle, but there are also acceptable precedents for the legislatures to follow. England does not have special provisions of the type mentioned earlier and it is of particular interest that in 1954 the British Parliament specifically repealed the former special provisions relating to public authorities. ${ }^{10:}$ The amending legislation was based on a report which stressed the injustices of the pre-existing situation and the confusion in interpretation to which it gave rise. ${ }^{101}$ In addition both Alberta and Manitoba have recently moved towards a rationalization of time periods in torts actions."': This has been achieved in part by abolition of many of the special time periods. In Alberta, the redundant time provisions have been excised from the relevant legislation, and where special provisions have been retained they have been transferred to the general statute. ${ }^{\text {us }}$ In Manitoba the common time periods and the general remedial provisions have been im-

103 It cannot be sald that the Canadian courts are unmindful of the diffleulties which the physician faces in the exerclse of his profession. See, e.g. Challand v. Bell (1959), 18 D.L.R. (2d) 150 (Alta. S.C.) and Marshall v. Curry, (1933) 3 D.L.R. 260 (N.S.S.C.) for examples of the utmost care that judges have taken to emphasize their appreciation of those difficulties.

104 Sumra, n. 4, at 173.

1us The Law Reform (Limitation of Actions, \& c.) Act, 1954, 2 \& 3 Eliz. 2, c. 26, 8. 1.

10n Report of the Committee on the Limitation of Actions, 1949. Cmnd. 7740, pp. 4-8.

10 i Supra, n. 3 .

10* S.A. 1966, c. 49 , s. $53-56$ and 8. 4. 
ported into the special legislation by specific cross reference in the amended general statute. ${ }^{109}$

A second and complementary expedient which should be considered is the synchronization of the different torts actions within the general statutes. Unless there are good practical reasons for distinction in time between different types of damage stemming from a common cause of action, or between different causes of action, a uniform period should be applied. Interestingly enough it was the Uniform Act of 1931 which introduced a significant variance in time periods into domestic limitation legislation. In the original English statute of James I, which is followed in five provinces, the common denominator for both trespass and case, except where the trespass was to person and the action in case involved words, was six years. ${ }^{110}$ In the Uniform Act which is retained in its virgin form in two provinces and the Arctic Territories, two years is the period laid down for defamation, trespass to the person and negligence resulting in personal injury, and six years for trespass to or negligence causing damage to chattels or land. ${ }^{121}$ In all other tort actions the period is six years. More recently Manitoba which had adopted the latter pattern has changed the period for damage to chattels from six to two years. ${ }^{112}$ In the most dramatic rationalization to date the Alberta legislature has prescribed a common period of two years for defamation, all forms of trespass, and negligence (except presumably negligence resulting in financial loss)..$^{113}$

If there are sound reasons for having different time periods they have never been exposed and the writer is hard put to speculate on what they might be. There may be an argument that in personal injury cases it is important to reconstruct the circumstances as soon as possible so that meaningful testimony can be rendered by the parties and witnesses. ${ }^{11+}$ This, however, assumes that the type of situations which give rise to these claims are fundamentally different from those involving property damage. This, of course, is nonsense. Property damage may result from exactly the same or similar type of incident as personal injury, and it is not likely to be any less instantaneous. Property damage is not necessarily any more permanent than personal injury, and there is nothing to indicate that discovery is more of a problem where property damage rather than physical injury is at issue. The suspicion is left in one's mind that the distinctions stem either from some inflated view of the importance of property rights or from lack of courage in carrying rationalization through to its logical limits. ${ }^{11 .}$ In addition to the lack of any practical reason for these distinctions, it may be doctrinally embarras-

100 Supra, n. 59.

310 Statute of Limitations 1623, 21 Jac. 1, c. 16, s. 3, followed in R.S.B.C. 1960, c. 370 , S. 3; R.S.N.B. 1952, c. 133, ss. 4. 9 (The pertod for trespass to the person is 2 years): R.S. N'Ad. 1952, c. 146, s. 2; R.S.N.S. 1967. c. 168, s. 2 (the period for trespass to the person and slander is one year, and for libel is 6 years); R.S.O. 1960. c. 214. 8. 45 .

111 R.S.P.E.I. 1951, c. 87, s. 2; R.S.S. 1965, c. 84, s. 3; R.O.N.W.T. 1956, c. 59, s. 3: R.O.Y.T. 1958, c. $66,8.45$.

112 S.M. 1966-67, c. 32, 8. $3(1)(t)$.

113 S.A. 1966, c. 49, s. 51.

114 Salmond, supra, n. 29, at 777.

115 It is interesting to note that in the early drafts of the Uniform Act a 4 year pertod for damage to property was canvassed. For some reason which is not explalned in the reports of the Uniformity Commissioners the suggestion was later dropped. For the early drafts, see the Proceedings of the $10 \mathrm{th}$ and 11 th Annual Meetings of the Conference of Commissioners on Uniformity of Lesislation in Canada 1927 \& 1928, at 53 and 66 respectively. 
sing where the Courts seek to inject some rationality into the substantive pattern of liability. ${ }^{116}$

An additional source of perplexity is the question of the appropriate limitation period for negligent misstatement resulting in financial loss. This, of course, has only recently been recognized as a viable cause of action and is not dealt with specifically in the prevailing limitation statutes. This is true even in Alberta and Manitoba where significant amendments have been made within the last three years. ${ }^{11}$ The response of the courts to this problem could well depend on the vintage of the limitation provisions which they are called upon to apply. In provinces which retain the old English legislative pattern the judges might conceivably use the existing phrase 'action upon the case for words', for which the period is two years, to accommodate the new cause of action. ${ }^{11}$ In the provinces which have a revised pattern it is probably safe to assume that the new action will fall under the common six year period for causes which are not specifically mentioned in the statutes. ${ }^{119}$ A dichotomy of this sort defies rational explanation and it is important that in any projected legislative reform a uniform approach is adopted in relation to this species of negligence. As in the case of property damage serious thought needs to be given to the question of whether this type of loss merits any greater concern in terms of actionability than personal injury. The 'negligent attorney' cases do indicate that there is a problem with the time it sometimes takes for financial loss to materialize or to reveal itself and this might be felt to constitute a reason for prescribing a longer period. It is at least doubtful, however, whether the problem is any greater than that which arises with personal injury in medical malpractice litigation. Another argument which might be raised in favour of a different period is the similarity between negligence in the context of the 'special relationship' stressed in Hedley Byrne v. Heller."1 $^{1: n d}$ negligence in the context of a contract for professional service. The obvious implication would be that the limitation period applicable to the latteri21 should be extended to the former. The attractiveness of this argument, however, depends on the validity of considering negligence in the performance of professional services in contractual terms. As will be indicated later the courts have not been consistent in adopting this approach and the time may well have come to stress the tortious character of the defendant's conduct."1:2 If this is accepted then the contractual analogy loses its force. Again, the logic of prescribing a special limitation period may be questioned.

If it is found that the reasons for distinct limitation periods are more imaginary than real then the same limitation period should be set for all common law tort actions. The length of the period is, of course, a matter for discussion and consultation. ${ }^{23}$ It can probably be safely

11 is See the critical comments on the Franics case, supra, pp. 160-1.

11 i Supra. n. 3. The same is true of the less drastic revisions of the Nova Scotia statute, R.S.N.S.. 1867, c. 168 .

11 R R.S.B.C. 1960 , c. 370 , s. 3; R.S.O. 1960 , c. 214 , s. $45(1)$ (1); R.S. N't1d. 1952. c. 146. s. 2.

110 R.S.A. 1955, c. 177, s. 5(1)(j); R.S.P.E.I. 1951, c. 87, s. $2(1)$ (B): R.S.S. 1965, c. 84. s. 3(1) (h): R.S.M. 1966-67, c 32, s. 3(1) (c); R.O.N.W.T. 1956, c. 59. s. 3(1) (j); R.O.Y.T. 1956, c. 66, s. $3(1)(j)$.

$120)[1964]$ A.C. 465 (H.L.).

121 Across common law Canada the limitation period for breach of contract is 6 years. 122 See infra, pp. 266-7.

123 Full consultation with those individuals and groups likely to be most closely affected by such a change is essential. This was the approach used by both the Davies Committee, supra, n. 40, and the Tucker Committee, supra, $n$. 106. in the U.K. 
asserted that, given the expedition of modern court procedures, the ready availability of testimony and the present speed of communications, six years is too lengthy a period and encourages unnecessary delay. ${ }^{124}$ A figure should be chosen which relates to the realities of modern litigation and balances in that light the plaintiff's interest in taking time to deliberate before he sues against the defendant's interest in being free as quickly as possible from subjection to suit. As an additional element of rationalization it might be useful for the legislators rather than trying to refer to each cause of action individually to consider formulating a general provision which would merely prescribe a common time period for 'all actions founded on tort'. This approach which was adopted by the English Limitation Act of 1939'ss has the merits of simplicity in form as well as flexibility in allowing for the future inclusion of new causes of action. ${ }^{12 i}$

Whether legislative reform in limitations can produce some order out of the confused inter-action between contracts and tort is also worthy of consideration. As already indicated there are some actions which, though they may be framed in negligence, have been traditionally viewed by the courts in a contractual context. Accordingly the limitation period applied is that prescribed for contract and time runs from the date of breach rather than that of the damage. This is the approach adopted in the lawyer-client cases ${ }^{12:}$ and has recently been extended in England to other professional relationships (for example, architect and client)..$^{1 *}$ However, the courts are by no means consistent where contract and tort coincide and there are other relationships involving contracts, such as those between the common carrier and passenger, employer and employee and physician and patient in which liability for injury or damage has traditionally been treated as tortious. ${ }^{20}$ Further, there are practical problems and paradoxes which follow from the approach of cases like Howell v. Hughes. ${ }^{130}$ In the first place, while it may make doctrinal sense to distinquish the situation from pure negligence on the grounds that the plaintiff has an action for nominal damages before the damage occurs or is discovered, such a right even if it could be pursued, is little consolation when he has no means of recovering his real loss. Secondly, it seems odd that the presence and absence of consideration in two situations which are otherwise identical in their substantive content has the effect of subjecting the plaintiffs to different time periods and different starting points. The recent report of the Alberta Uniformity Commissioners goes some way to suggesting a solution to this problem by advising that a provision be included in future limitation legislation making it clear that claims for

12. All of the legislative amendments made so far in both Canada and the U.K. seem to reflect this feeling to one degrec or another.

196 The Limitation Act, 1939, 2 \& 3 Geo. 6, c. 21, s. 2(1) (b).

1i: It would, of course, then be for the courts to apply the common time period to the individual causes of action. There would still be differences in practice in the application of the common period, because of the varied effect of the several causes on the running of time.

1:- See, e.g. Howell v. Hughes, supra, n. 12; Groom v. Crocker, [1938] 2 All E.R. 394 (C.A.): Clark v. Kirby-Smith, |1864| 2 All E.R. 835 (Ch.D.): Frind v. Sheppard, supra, n. 31: Schwebel v. Telekes, sumra. n. 30.

1.: Bagot v. Stevens. Scanlan \& Co.. |1964| 3 All E.R. 577 (Q.B.D.).

$1: 0$ See Poulton, supra, $n$. 14. Even in the context of these relationships courts sometimes exhibit doubts. See, e.g. Homenick v. Wiebe (1965), 50 D.L.R. (2d) 287 (Man. C.A.). The plalntiff was injured while operating an autoboggan for hls employer. The Court of Appeal criticized the trial judge's summary rejection of the areument that the action was in contract rather than tort.

130 Supra, n. 12. 
personal injury or property damage caused by negligence in the performance of a contract should be treated as tort actions.. ${ }^{181}$ This would mean that the limitation periods would be identical and would run from the same point in time. In principle the suggestion is a sound one in that it seeks to counteract the problem not by the radical expedients of prescribing a common period for torts and breach of contract or of distinguishing certain types of breach of contract from the main body, but by extending the rationalization of the characterization process already evident in case law. It may be questioned, however, why the suggestion should not be extended to negligence resulting in financial loss. Since the decision in Hedley Byrne Ltd. v. Heller \& Partners ${ }^{\text {s: }}$ the problem of procedural discrimination is just as much of an issue there. Perhaps a more successful basis for such a rule would be to postulate with Mr. Poulton that where the situation is one in which a plaintiff would be able to sue in tort in the absence of a contract he should be allowed to frame his action in tort where a contract does happen to exist. 1:it Accordingly contract would be the appropriate action only where actionability depended upon it. This would be sufficiently comprehensive to cover all the difficult fact situations involving belated discovery that have given or may give the courts trouble and at the same time provide a thoroughly credible and relatively predictable characterization process. ${ }^{134}$

There are two specific suggestions as to devices which will balance the equities of limitation in favour of the plaintiff. The shorter the period prescribed for actionability the more important it becomes to allow the courts discretion in dealing with hard cases. In the first place a general discretion should be granted to the courts by legislation, allowing the plaintiff to amend his claim even though the amendment raises a new cause of action and would in the normal way be statute barred. This would provide for situations not covered by the decision in Franks v. Cahoon ${ }^{13 i}$ and would allow the courts to avoid the difficult task of deciding whether the amendment does in fact raise a new cause of action. The Alberta Uniformity Commissioners very sensibly advocate the general adoption of a section similar to that contained in the Saskatchewan Queen's Bench Act. ${ }^{131}$ The gist of the latter provision is that the court may permit the amendment of any pleading or proceeding, on such terms as it deems just, notwithstanding that between the time of issuance of the original writ and the application for amendment, the right of action would have been barred by statute. The section does not apply where the amendment involves a change of party, except where the change is necessitated by death. It may well be questioned whether there is any great value in this latter restriction. Recent experience in England suggests that there are cases where a plaintiff quite innocently sues the wrong party and only discovers this

131 Supra, n. 4 , at 175

1ง: Supra, n. 120.

133 Poulton. supra, n. 14, at 368-370.

134 It would certainly be preferable to the solution suggested in Paramuschuk v. Meadow Lake (1965). 47 D.L.R. (2d) 427 by the Saskatchewan Court of Appeal, that the plaintiff should have an option of whether to sue in tort or contract. 
when time is past. ${ }^{13-}$ It seems only fair that the same consideration granted by the general provision to other difficult circumstances should be extended to this type of situation.

The second and more significant expedient is a provision allowing time to run from the date of discovery of the basis of a cause of action where it was impossible for the plaintiff to have discovered this at any earlier stage. An initial question which arises is whether the remedial amendment should be extended to all causes of action or confined to a few. The United Kingdom and Manitoba statutes are a trifle ambiguous on this issue. The use of the wording 'negligence, nuisance or breach of duty'138 suggests that the draftsman did not see the provision as all pervasive. If he had meant it to cover all causes of action then he could surely have said so with more lucidity. However, the looseness of the term 'breach of duty' is such that it may well leave some room for flexibility in interpretation. ${ }^{130}$ Unless it can be established that the problem of belated discovery is one which by its nature is confined to a limited group of causes it seems to the writer that both justice and clarity would be better served by an amendment of an openly comprehensive character.

It will also be important to consider whether the new provision should be confined to personal injury cases ${ }^{140}$ or extended to other forms of damage. The comment was ventured earlier that the problem of belated discovery may well exist with other types of loss although it may have been offset to some degree in the past by longer limitation periods. ${ }^{1+1}$ However, if a common and fairly modest limitation period is found to be both desirable and practical then the problem with property damage and financial loss may become more real and a remedial provision more appealing.

It has on occasion been maintained that the problem of discovery in personal injury cases is more apparent than real in Canada. The problem, it is said, generally develops in an industrial context when a workman contracts an insidious disease as a result of the alleged negligence of his employer and is consequently the sole concern of the several Workmen's Compensation Boards. ${ }^{1+2}$ A few cautionary words need to be offered on this point of view. In the first place insidious diseases are no respecters of jurisdictional boundaries and it is not unlikely that with the continuing subjection of mankind to the noxious by-products of technological advance the problem will present itself outside the strictly industrial context. Secondly, medical malpractice cases are productive of this type of problem and experience has already indicated that Canadian courts are not immune from litigation in which

13: See, Re Clark y. Forbes Stuart (Thames Street) Ltd. [1964] 2 All 2.R. 282 (C.A.). The plaintiff who was injured on premises while collectins a load of fish issued a writ against the company he thought to be the occupiers, Forbes Stuart (Billingsgate) Ltd., and later, after the expiry of the limitation period, found that the occuplers were in fact Forbes Stuart (Thames Strect) Ltd. The issue here was resolved in favour of the plaintiff on an interpretation of the Limitation Act. 1963.

For the broader implications of mistaken identity, see Goodman. First catch your Defendant-Limitation and the Unknown Tortfeasor (1966), 29 Mod. L. Rev. 366.

1:s Surra, n. 48, s. $1(2)$; s. 11 A (2).

1:1: It is interesting to note that in Letang v. Cooper, supra, $n$. 88, and Long v. Hepworth, (1968) I W.L.R. 1299 (Q.B.D.) 'breach of duty' in the 1954 'Limitation Act, s. 2(1). was interpreted to include the action of trespass to the person. In both cases the courts opined that the tcrn covered any breach of duty under the law of tort.

ito The United Kingdom and Manitoba Acts are so confined. See, supra, n. 48, s. 1(2): s. $11 \mathrm{~A}(2)$.

$1+1$ Supra, p. 252.

it: See Bowker, supra, n. 1, at 42: Proceedings of Uniformity Commissioners, supra, n. 4. at 176. 
it constitutes the cardinal issue. ${ }^{1+3}$ Thirdly, even commonplace accidents may present difficulties for the plaintiff in that he will be unable to establish immediately the existence or seriousness of his damage or injury, or, if he does, that it is related in any way to an act or omission of the defendant.144 Finally it is probably safe to assume that the true significance of the problem has been concealed by its deterrent effect on the launching of actions. Concern with belated discovery in this context is therefore by no means academic.

Given that the need for such a provision is recognized the question of what form it should take arises. Both the English and Manitoban provisions are lengthy and involved and it is legitimate to ask whether they need to be emulated in all their details. The validity of the English requirement of separate ex parte proceedings 1 1" may be questioned. Surely the issue of whether the plaintiff can adduce prima facie proof that he was unable to bring his action earlier can be dealt with just as fairly for both sides at trial. Further the justice of requiring the plaintiff, as do both existing statutes, ${ }^{2+1}$ to produce prima facie proof that, apart from limitation the action would succeed, may be doubted. This is not required in the orthodox limitation case where the courts make it quite plain that they are not purporting to judge the substantive issues. There is the added disadvantage that the plaintiff is required to reveal his evidence before the substantive issue is ever reached. It is suggested that both these devices should be avoided in domestic legislation. The question of discovery should be raised at trial and dealt with entirely as a procedural question. This is exactly the approach adopted by the sections relating to Scotland in the 1963 United Kingdom Act. ${ }^{14:}$

The question of the scope of the discretion and how closely it should be defined is difficult. As far as the writer can see there are three possibilities, and it is largely a question of how revolutionary the legislator wants to be as to which he chooses. In the first place the statute could indicate simply that the plaintiff may claim the protection of the exception if he can prove that he did not have knowledge, actual or constructive, ${ }^{1 \text { th }}$ of the facts essential to the launching of the particular cause of action. This would show that it is ignorance of fact that is crucial, and also that the ignorance must relate to the factual elements that are prerequisites of actionability. Thus, in the case of negligence the remedial provision would only be applied if there was unawareness of the existence of any damage or injury, or of any causal relationship between the plaintiff's loss and any act or omission of the defendant. Such an exception would be narrower than that adopted by the English and Manitoban provisions and might therefore still exclude situations where the plaintiff was in a difficult position as regards his ability to

143 See Miller v. Ryerson, supra n. 64; Tremeer v. Black, supra n. 67: Gloning v. Miller, supra n. 46.

144 See the Report of the Davies Committee, supra, n. 40, at 5. The Committee was unwilling to accept a 'superficlally attractive distinction' between 'disease' and 'accident" as a basis for its recommendations.

145 The Limitation Act $1963,11 \& 12$ Ellz. 2, c. 47, s. 5.

1411 Supra, n. 48, s. $7(4)$; 8. 11 G(6).

14 S Supra, n. 145, s. 8.

1. There seems to cvery justification for denying the protection of the remedial provision to a plaintiff who is himself remiss in falling to discover the facts which would form the basis of a cause of action. There is no good reason why the defendant should be penalized for the plaintiff's stupldity or lack of discernment. Any amendment should therefore follow the existing statutes in allowing the court in an appropriate case to determine whether the plaintiff's ignorance was reasonable. See supra, n. 48, s. 7; s. $11 G$. 
start an action. 19 It would however, have the advantages of brevity, clarity and certainty which would make its application fairly straightforward. At the other end of the scale the judges could be given a general discretion to allow belated claims where justice demands it. The advantage of this approach is that it would not confine the remedial principle to ignorance of the cause of action, but could be used in cases where it was not practical to bring an action earlier because of a lack of information as to its nature and extent or where an action had already been brought but at a time when there was incomplete knowledge of its character or gravity. The main snag with permitting such broad discretion is that it would invite the judges to make inroads into the present "all or nothing" pattern of awarding damages, without the sort of deliberation which is desirable in working such a fundamental change in the law. The third modus operandi would be to follow the lead of the two existing statutes and to seek a middle road between the two extremes. This would be achieved by extending protection some way beyond the ignorance of cause of action restriction to include situations where an earlier action was not brought because there was a lack of awareness of the nature or extent of the injury or damage. The formulation in the English and Manitoba statutes refer to three instances in which the ignorance of the plaintiff may carry the privilege with it-ignorance as to injury, to its nature or extent and to causal connection. Again this approach has the merit of being somewhat more flexible than the first. It does, however, give the impression of being a half measure, leaving the judiciary suspended tenuously between a certain, if limited, advance on the one hand and a radical change of policy on the other. As a half measure it would probably require greater elaboration within the statute than the other two approaches and this might well be productive of new sources of controversy. ${ }^{150}$ In the writer's opinion the first approach is to be preferred in that it provides a framework for action which is uncomplicated and not likely to produce great controversy. If the further step of injecting greater flexibility into the mechanies of awarding damages is considered desirable then that should be achieved by specific legislative reform, rather than by the 'back door' method of incorporation in a limitation act.

As far as the special time limit for launching the belated action is concerned the 12 month period prescribed by the existing statutes ${ }^{151}$ seems to represent a fair compromise between the interests of the parties allowing the plaintiff sufficient time to issue his writ and preserving the defendant from an extended period of uncertainty.

Ity Both statutes cover situations where the plaintiff's difflculty is not that he is unaware of his cause of action but that he does not know the nature or extent of his injuries. See supra, n. 48. s. $7(3)$; s. $11 G(5)$.

sou See the involved interpretative sections in each of the existing statutes. supra, $n$. 48, s. 7; s. 4J11G|. See also Re Pickles v. National Coal Board, |1968] 1 W.L.R. 997 (C.A.) in which the Court allowed an application under the Enslish part of the U.K. Act even though more than 12 months had explred since the plaintiff discovered that he had contracted an Industrial disease through working years before in the defendunt's colliery. The judges felt that as the plaintif had to attribute his injury to the negligence, nuisance or breach of duty of the defendant the operative date for the 12 month period to start running was when he received affirmative advice as to his legal rights against the defendant.

This is a clear departure from normal practice with limitation periods. Generally speaking their applicability is decided before any decision is made on substantive issues. Further time starts to run from the date that the course of action is consummated. not from the date that a lawyer decides that the claim is worth pursuing.

151 Supra, n. 48, s. 1(3); s. 11A(1). 


\section{Conclusion}

The courts have succeeded in resolving some of the problems that are involved in the application of limitation legislation to negligence actions. In particular, they have given body to the vague provisions in limitation acts as to the point at which time starts to run. They have been less successful in dealing with the problems created by belated discovery. This incapacity to assist the cause of the plaintiff is as much a product of the complex pattern of limitation legislation as it is of the natural caution of the Canadian judiciary. Where the courts have sought to do justice to plaintiffs, as for example in the Franks case, the expedient has been a partial one and productive of its own special problems. The obvious solution to the root problem is a comprehensive revamping of limitation legislation. This should include the abolition of the most of the special limitation periods contained in other statutes. Some attention should be paid to the rationale, if any, of different periods for different torts and different types of damage caused by the same tort. If there is no adequate reason for diversity a common time period which is fair to both parties should be selected. An attempt should be made to resolve the procedural conflict between contracts and torts law by allowing actions in tort except where actionability depends entirely on a contractual relationship. Finally, any legislative reforms should contain remedial provisions allowing for amendment out of time where justice demands it, and for the belated launching of an action where the existence of a cause of action was not apparent to the plaintiff any earlier. 